\title{
Insight into hypoglycemia in pediatric type 1 diabetes mellitus
}

\author{
Kimberly E Lehecka', Venkat S Renukuntla ${ }^{2}$ and Rubina A Heptulla ${ }^{3^{*}}$
}

\begin{abstract}
Hypoglycemia is a common complication of insulin treatment in type 1 diabetes mellitus and can occur in any patient with diabetes when glucose consumption exceeds supply. Many studies have been done to elucidate those factors that predict severe hypoglycemia: younger age, longer duration of diabetes, lower $\mathrm{HgbA}_{1,}$, higher insulin dose, lower Body Mass Index, male gender, Caucasian race, underinsurance or low socioeconomic status, and the presence of psychiatric disorders. Hypoglycemia can affect patients' relationships, occupation, and daily activities such as driving. However, one of the greatest impacts is patients' fear of severe hypoglycemic events, which is a limiting factor in the optimization of glycemic control. Therefore, the importance of clinicians' ability to identify those patients at greatest risk for hypoglycemic events is two-fold: 1) Patients at greatest risk may be counseled as such and offered newer therapies and monitoring technologies to prevent hypoglycemic events. 2) Patients at lower risk may be reassured and encouraged to improve their glycemic control. Since the risk of long-term complications with poor blood glucose control outweighs the risks of hypoglycemia with good blood glucose control, patients should be encouraged to aim for glucose concentrations in the physiologic range pre- and postprandially. Advancements in care, including multiple daily injection therapy with analog insulin, continuous subcutaneous insulin infusion, and continuous glucose monitoring, have each subsequently improved glycemic control and decreased the risk of severe hypoglycemia.
\end{abstract}

Keywords: Hypoglycemia, Diabetes mellitus, Insulin

\section{Definition}

Hypoglycemia is a common complication of insulin treatment in type 1 diabetes mellitus [1]. A safe blood glucose concentration varies with many factors, including rate of fall of blood glucose, duration of hypoglycemia, and age of the child [2]. Therefore, determining the precise and exact blood glucose that should be considered "low" is difficult. One common benchmark is $65-70 \mathrm{mg} / \mathrm{dl}(3.6-3.9 \mathrm{mmol} / \mathrm{L})$ because this is the concentration at which counter-regulatory mechanisms are triggered in persons without diabetes [3]. However, symptoms and the clinical significance associated with specific blood glucose concentrations vary with each individual, and it is common for patients with hypoglycemia to be unaware when their glucose is low

\footnotetext{
* Correspondence: rubina.heptulla@einstein.yu.edu

${ }^{3}$ Department of Pediatrics, Division of Pediatric Endocrinology, Albert Einstein College of Medicine/ The Children's Hospital at Montefiore, 3415 Bainbridge Ave, Bronx, NY 10467, USA

Full list of author information is available at the end of the article
}

$[4,5]$. Young children and infants with type 1 diabetes mellitus (T1DM) represent additional difficulty in recognizing hypoglycemia because they are unable to recognize and also communicate their warning symptoms to their caregivers [6].

Despite the aforementioned difficulties associated with assigning strict categories, the American Diabetes Association's Workgroup on Hypoglycemia has formed a classification system in an attempt to aid communication amongst clinicians and researchers. In general terms, they define hypoglycemia as "an abnormally low plasma glucose concentration that exposes the individual to potential harm." They further define hypoglycemic events as:

a) Severe hypoglycemia. An event in which the patient with diabetes suffers neuroglycopenia to the point of requiring the help of another to administer carbohydrate, glucagon, or other resuscitative measures, sometimes to the point of seizure or loss of consciousness, and including coma or death. Even

\section{Ciomed Central}


if plasma glucose level is unrecorded during such an episode, recovery attributed to normalization of plasma glucose concentration is sufficient to qualify the event as severe hypoglycemia.

b) Documented symptomatic hypoglycemia. Measured plasma glucose levels $\leq 70 \mathrm{mg} / \mathrm{dl}(3.9 \mathrm{mmol} / \mathrm{L})$ that is associated with typical hypoglycemic symptomatology. Hypoglycemia may present as mood or behavioral changes, especially in young children, or more classically as autonomic symptoms such as hunger, sweating, palpitations, tremor, and confusion.

c) Probable symptomatic hypoglycemia. Episodes when a patient with diabetes reports typical hypoglycemic symptoms in which the blood glucose level is unrecorded

d) Asymptomatic hypoglycemia. Measured plasma glucose levels $\leq 70 \mathrm{mg} / \mathrm{dl}(3.9 \mathrm{mmol} / \mathrm{L})$ without typical hypoglycemic symptomatology.

e) Relative hypoglycemia- Episodes of patient with diabetes-reported typical hypoglycemic symptoms associated with measured plasma glucose levels of $>70 \mathrm{mg} / \mathrm{dl}(3.9 \mathrm{mmol} / \mathrm{L})$ [4].

\section{Etiology}

In the simplest of terms, hypoglycemia is the result of glucose consumption in excess of glucose availability [7]. In T1DM, it is primarily the result of supra-therapeutic insulin doses, which lack physiologic feedback inhibition in response to low blood glucose concentration [8]. In addition, hypoglycemic counter-regulatory measures are affected by diabetes. In patients with diabetes, pancreatic $\alpha$-cells fail to secrete glucagon in response to low blood glucose. This is thought to be due to a signaling defect associated with a lack of endogenous insulin production, since the glucagon response to other stimuli remains intact [9]. Epinephrine, norepinephrine, and cortisol responses to hypoglycemia are also blunted in children and adolescents with well-controlled diabetes [10]. Hypoglycemia-associated autonomic failure syndrome is a description of the "vicious cycle" that results in inadequate epinephrine secretion: recent antecedent episodes of hypoglycemia (as often occur in diabetics on intensive insulin therapy) cause a reduction in the epinephrine response to subsequent hypoglycemic events and lower the glucose level required before the epinephrine response is triggered. Furthermore, patients are often unaware of the fact that they are hypoglycemic and therefore do not take action to reverse this state [11].

Severe hypoglycemia involving loss of consciousness is understood to be due to neuroglycopenia, as brain cells lack the glucose necessary for normal functioning [12]. The mechanism of hypoglycemic seizures is presently unknown. In animal studies, it appears that the
Substantia Nigra Pars Reticulata (SNR) is involved in regulating hypoglycemic seizures. Fasting causes both the amount of Gamma-aminobutyric Acid (GABA) and ATP-dependent potassium channels in the SNR to decrease, which may predispose the subject to seizure when severe hypoglycemia is induced $[13,14]$. In addition, hypoglycemia induces gene expression changes in choline acetyltransferase and acetylcholinesterase gene expression in the cerebellum. The subsequent cerebellar dysfunction may be associated with seizure generation as brain cells lack the glucose they need to function [15].

\section{Importance}

Good glycemic control is essential in reducing the risk and delaying the onset of long-term complications of T1DM such as retinopathy, neuropathy, and nephropathy. However, the Diabetes Control and Complications Trial (DCCT) also showed that strict glycemic control with intensive insulin management is associated with an increased risk of severe hypoglycemic events when compared to conventional treatment [16].

Hypoglycemia can affect patients' relationships, occupation, and daily activities such as driving $[17,18]$. However, one of the greatest impacts is patients' fear of severe hypoglycemic events, which is a limiting factor in the optimization of glycemic control $[19,20]$. Therefore, the importance of clinicians' ability to identify those patients at greatest risk for hypoglycemic events is two-fold:

1) Patients at greatest risk may be counseled as such and offered newer therapies and monitoring technologies to prevent hypoglycemic events.

2) Patients at lower risk may be reassured and encouraged to improve their glycemic control [9].

\section{Incidence with various treatment modalities}

Various regimens are used to treat patients with diabetes, which include:

a) Conventional therapy. Once-daily blood or urine glucose monitoring, one to two daily insulin injections of mixed intermediate and rapid-acting insulin's, diet and exercise.

b) Intensive insulin therapy or multiple daily injections (MDI). At least four glucose checks daily, three or more insulin injections daily with short-acting insulin before meals; dosages based on planned dietary intake, exercise, and finger-stick blood glucose values [16].

c) Continuous subcutaneous insulin infusion (CSII). An insulin pump is used to deliver a constant basal rate 
of insulin, with patient-programmed boluses based on dietary intake, exercise, and capillary blood glucose values.

d) Continuous glucose monitoring (CGM). A continuous glucose monitor is used to measure the patient's blood glucose on one to five minute intervals, so the patient may then program their insulin pump to deliver medication accordingly. Alarms may be set to alert the patient when glucose is especially high or low. After the DCCT drew attention to the importance of glycemic control, patients with diabetes were generally transitioned from conventional therapy to MDI, which resulted in reduced hemoglobin $\mathrm{A}_{1 \mathrm{c}}\left(\mathrm{HbA}_{1 \mathrm{c}}\right)$ values [21]. However, this was associated with a three-fold increase in severe hypoglycemic episodes [22]. Use of analog insulin's such as Lispro (Humalog) in MDI further improved glucose control without increasing the rate of severe hypoglycemia [23,24].

Studies with a small sample size have demonstrated various effects of switching from MDI to CSII, ranging from slight to moderate improvement in $\mathrm{HbA}_{1 \mathrm{c}}$, and decreasing to increasing rates of hypoglycemia (this variation is especially evident in young children) [25-27]. Findings of these studies are summarized in Table 1. The largely-improved rates of severe hypoglycemic episodes may be partially due to a move from Neutral Protamine Hagedorn Insulin (NPH) to long-acting insulin such as glargine [28].

In patients with T1DM who are prone to hypoglycemia on MDI, meta-analysis shows the rate of severe hypoglycemia is lessened with CSII, with a rate ratio of 4.19 (2.86 to 6.13). This effect is strongest for patients with the highest frequency of hypoglycemia on MDI, and adult patients who presumably have had a longer duration of diabetes (which is associated with greater risk of hypoglycemia). In addition, $\mathrm{HbA}_{1 \mathrm{c}}$ on CSII is reduced $0.2-0.62 \%$ when compared to MDI, where patients with the worst blood glucose control on MDI receive the most benefit from CSII $[29,30]$. However, in another meta-analysis, children were shown to have 0.68 more episodes of minor hypoglycemia perweek on CSII [29]. Continuous glucose monitoring is currently in use to further intensify glucose control by providing real-time feedback that helps patients anticipate and prevent hypo- and hyperglycemic events. In adult patients, use of CSII + CGM improved glycemic control when compared to MDI alone, MDI + CGM, or CSII alone, without an associated increase in severe hypoglycemia [31-34] (Table 1).

\section{Individual risk factors}

In the Diabetes Control and Complications Trial (DCCT), factors that predicted severe hypoglycemia in patients on intensive management included a history of severe hypoglycemia, duration of diabetes, higher baseline $\mathrm{HbA}_{1 \mathrm{c}}$, and lower recent $\mathrm{HbA}_{1 \mathrm{c}}$ [35]. Since the DCCT, several studies have found increased incidence of severe hypoglycemia in those patients exhibiting the characteristics listed in Table 2.

It is important to note that in the study by Allen et al. [36], older age was predictive of adverse outcomes. This is in opposition of the predictive nature of younger age, as found by Rewers et al. [37] and Bulsara et al. [24]. It is likely that Allen et al.'s finding of older age represents the longer duration of diabetes experienced by older subjects, which is corroborated by the other studies, rather than a truly different conclusion.

Patients with previous episodes of severe hypoglycemia have an increased risk for subsequent events [36-38]. Other risk factors associated with recurrent severe hypoglycemia are increased duration of diabetes and underinsurance, at least in adolescents $>13$ years of age [36]. However, it is important to note that frequent episodes of mild hypoglycemia are not a risk factor for severe hypoglycemia $[37,38]$.

Conversely, a recent study of 108 adolescents showed no significant difference between teenagers who had at least one episode of severe hypoglycemia in the previous year and teenagers without severe hypoglycemia when comparing $\mathrm{BMI}, \mathrm{HbA}_{1 \mathrm{c}}$, insulin dose, caloric intake, race, gender, parental education level, parental marital status, and annual family income [39].

\section{Effect of hypoglycemia on cognition}

One of the major theoretical concerns surrounding low blood glucose is the long-term cognitive effects of hypoglycemia to the point of neuroglycopenia. It is known that profound hypoglycemia (blood glucose $<18 \mathrm{mg} / \mathrm{dL}$ ) can cause cerebral energy failure, neuronal necrosis, and cessation of electrical brain activity if maintained for an extended period [40]. However, it is reassuring that prior recurrent episodes of moderate hypoglycemia were found to be protective against neuronal damage and cognitive dysfunction due to profound hypoglycemia in rats [41].

Less severe episodes of hypoglycemia (blood glucose $50-65 \mathrm{mg} / \mathrm{dL}$ ) are of more concern to the vast majority of patients with diabetes. These events result in transient cognitive defects, which can impact concurrent activities such as driving [18], but these fortuitously fail to show long-term cognitive consequences. Specifically, the DCCT showed that neither treatment regimen (conventional vs. multiple daily injection therapy) nor frequencies of severe hypoglycemia were associated with a 
Table 1 Studies comparing multiple daily injections (MDI) vs. continuous subcutaneous insulin infusion (CSII) in pediatric patients

\begin{tabular}{|c|c|c|c|c|}
\hline Author & Study Design & HbA1c & Hypoglycemia & Other findings \\
\hline \multirow[t]{2}{*}{ DiMeglio et al. } & $\begin{array}{l}\text { - } 42 \text { children }<5 y / 0 \text { with } \mathrm{DM}>1 \text { yr were } \\
\text { randomly assigned to CSII or MDI }\end{array}$ & \multirow{2}{*}{$\begin{array}{l}\text {-Improved blood glucose } \\
\text { both groups, with better } \\
\text { control in CSII group at } \\
3 \mathrm{~m} \text {, no difference at } 6 \mathrm{~m} \\
\text { follow up }\end{array}$} & $\begin{array}{l}\text { - CSII children had increased } \\
\text { meter-detected hypoglycemic } \\
\text { events }\end{array}$ & \multirow[t]{2}{*}{$\begin{array}{l}\text { - High satisfaction rate } \\
\text { with CSII }\end{array}$} \\
\hline & $\begin{array}{l}\text { - HbA1c, severe hypoglycemia, meter- } \\
\text { detected hypoglycemia, blood sugar } \\
\text { variability, BMI, and satisfaction with } \\
\text { therapy were checked at baseline, } \\
3 \text { m \& } 6 \text { m }\end{array}$ & & $\begin{array}{l}\text { - Both groups had one } \\
\text { hypoglycemic seizure }\end{array}$ & \\
\hline \multirow[t]{4}{*}{ Litton et al. } & $\begin{array}{l}\text { - } 9 \text { toddlers with DM and history of } \\
\text { severe hypoglycemia and ketoacidosis } \\
\text { were treated with MDI for a mean of } \\
13.7 \mathrm{~m} \text {, followed by CSIl for a mean of } \\
12.7 \mathrm{~m}\end{array}$ & $\begin{array}{l}\text { - MDI HbA1C average } \\
9.5 \% \pm 0.4 \%\end{array}$ & $\begin{array}{l}\text { - MDI: mean } 0.52 \\
\text { episodes/month }\end{array}$ & $\begin{array}{l}\text { - Normal growth \& } \\
\text { development on pump } \\
\text { therapy }\end{array}$ \\
\hline & \multirow[t]{3}{*}{$\begin{array}{l}\text {-HbA1c, severe hypoglycemia, growth } \\
\text { and development, contact with } \\
\text { healthcare professionals, and } \\
\text { satisfaction with therapy were followed }\end{array}$} & \multirow[t]{3}{*}{$\begin{array}{l}\text { - CSII HbA1c average } \\
7.9 \% \pm 0.3 \%(p<0.001 \\
\text { difference) }\end{array}$} & \multirow[t]{3}{*}{$\begin{array}{l}\text { - CSII: mean } 0.09 \\
\text { episodes/month }\end{array}$} & $\begin{array}{l}\text { - No change in frequency } \\
\text { of physician or ER visits } \\
\text { for acute hyperglycemia } \\
\text { or ketoacidosis }\end{array}$ \\
\hline & & & & $\begin{array}{l}\text { - }>80 \% \text { decline in } \\
\text { contact with healthcare } \\
\text { professionals indicating } \\
\text { more independence }\end{array}$ \\
\hline & & & & $\begin{array}{l}\text { - Subjective improvement in } \\
\text { quality of life, satisfaction } \\
\text { with CSII }\end{array}$ \\
\hline \multirow[t]{2}{*}{ Hanas et al. } & $\begin{array}{l}-1 \text { year cross-sectional study of } \\
7-21 \text { year old patients, with } 27 \text { on CSII } \\
\text { and } 62 \text { on } \mathrm{MDI}\end{array}$ & - MDI HbA1c 8.2\% $\pm 1.6 \%$ & MDI incidence of: & $\begin{array}{l}\text { - No admissions for } \\
\text { ketoacidosis in either } \\
\text { group during cross- } \\
\text { sectional study year }\end{array}$ \\
\hline & $\begin{array}{l}\text { - HbA1c, severe hypoglycemia, } \\
\text { and ketoacidosis were followed, } \\
\text { with } 5 \text { year follow-up of } \\
\text { CSIl patients }\end{array}$ & $\begin{array}{l}\text { - CSII HbA1c } 8.9 \% \pm 1 \% \text {, } \\
\text { however } 67 \% \text { of patients had } \\
\text { high HbA1c as the reason } \\
\text { for CSII therapy. } \\
\text { Mean baseline } 1 y \\
\text { before study } 9.5 \% \text {, lowered to } \\
8.9 \% \text { at } 1 \text { and } 5 \text { year follow-ups }\end{array}$ & $\begin{array}{l}\text { - Severe hypoglycemia } \\
- \\
40.3 / 100 \text { patient years } \\
\text { - With unconsciousness- } \\
\text { 12.9/100 patient years } \\
\text { - Seizures- } \\
9.7 / 100 \text { patient years } \\
\text { CSII incidence of: } \\
\text { - Severe hypoglycemia- } \\
\text { 11.1/100 patient years } \\
\text { - No episodes with } \\
\text { unconsciousness or seizure }\end{array}$ & $\begin{array}{l}\text { - } 5 \text { year follow up } \\
\text { of CSIII patients revealed } \\
\text { incidence of ketoacidosis } \\
\text { of } 4.7 / 100 \text { per patient year, } \\
\text { indicating low risk }\end{array}$ \\
\hline
\end{tabular}


Table 2 Risk factors for severe hypoglycemia

\begin{tabular}{lr}
\hline Risk Factors for Severe Hypoglycemia & Reference number \\
\hline Younger age & $(30)(18)$ \\
\hline Longer duration of diabetes & $(30)(18)$ \\
\hline Male gender & $(30)(18)$ \\
\hline Caucasian race & $(30)$ \\
\hline Lower HbA $1 c$ & $(30)(31)(18)$ \\
\hline Higher insulin dose & $(18)$ \\
\hline Lower BMl & $(30)$ \\
\hline Lower socioeconomic status or Underinsurance & $(31)(18)$ \\
\hline Psychiatric disorders (thought to be due to & \\
infrequent capillary blood glucose testing \\
and chaotic lifestyle)
\end{tabular}

cognitive decline over a mean 18 year follow up [42-44]. In meta-analysis, hypoglycemic seizures in children with diabetes conferred inconsistent, clinically insignificant cognitive defects and most current research fails to suggest a detrimental effect of hypoglycemia [45-48].

Individual studies show a variety of neuropsychological effects of diabetes mellitus on children, with early onset of diabetes having the greatest negative influence on cognition [45]. Higher $\mathrm{HbA}_{1 \mathrm{c}}$ values, as found in patients on conventional therapy, were associated with moderate declines in psychomotor efficiency (even when patients with stroke, visual impairment, and renal disease were excluded) and motor speed (when the entire study group was analyzed), although this was not evident in adolescent patients $[42,43]$.

\section{Nocturnal hypoglycemia and post-exercise nocturnal hypoglycemia}

Nocturnal hypoglycemia is defined as a blood glucose value $<70 \mathrm{mg} / \mathrm{dL}$ after bedtime. Nocturnal hypoglycemia is frequent (twice per month, on average) and often prolonged ( $81 \%$ of episodes were longer than 1 hour in one study) in adults and children with T1DM, especially in those patients who are treating their disease aggressively $[49,50]$. Hypoglycemia is more likely to occur during the night if a patient has exercised during the preceding afternoon, a phenomenon known as postexercise nocturnal hypoglycemia [51].

In a study by the Juvenile Diabetes Research Foundation (JDRF) Continuous Glucose Monitoring Study Group, nocturnal hypoglycemia was associated with lower $\mathrm{HbA}_{1 \mathrm{c}}$ values, was most common in patients aged 15-24 years old, and more likely to be prolonged in those patients $<25$ years old. The same study showed no significant difference in the frequency of nocturnal hypoglycemia when comparing MDI and CSII therapy. On an individual basis, a lower bedtime blood glucose level has been shown to be a significant predictive factor for nocturnal hypoglycemia, while values $>130 \mathrm{mg} / \mathrm{dl}$ before a bedtime snack correlate with a lower likelihood $[51,52]$.

Various measures have been investigated to determine what may be done to prevent nocturnal hypoglycemia. In a study by Raju et al., a conventional snack, a snack plus acarbose (an $\alpha$-glucocidase inhibitor), and an uncooked cornstarch bar all delayed the onset of nocturnal hypoglycemia, but did not prevent it from occurring [50]. Administration of the $\beta$-adrenergic agonist Terbutaline at bedtime has been shown to prevent nocturnal hypoglycemia, but is associated with the undesirable effect of hyperglycemia $[50,53]$. In a study by Taplin et al., reduction of basal insulin in patients on insulin pump therapy was shown to be a safe and effective method of raising the blood glucose nadir and preventing postexercise nocturnal hypoglycemia [53]. The delay between the onset of nocturnal hypoglycemia and the occurrence of a severe hypoglycemic event (seizure) appears to be significant on the order of 2-4 hours, according to one very small report, indicating that continuous glucose monitoring and alarms may help prevent the most dreaded potential side effects of nocturnal hypoglycemia [54].

Traditionally, morning fasting hyperglycemia is attributed to activation of counter-regulatory mechanisms or a fall in insulin levels after an episode of nocturnal hypoglycemia, termed the Somogyi phenomenon. However, the veracity of this phenomenon has long been questioned, and new studies with continuous glucose monitoring have further detracted from this hypothesis $[55,56]$. One study observed that only $23 \%$ of episodes of morning hyperglycemia were consistent with the Somogyi phenomenon (i.e. were associated with nocturnal hypoglycemia), while $77 \%$ of episodes were associated with overnight euglycemia or hyperglycemia [56].

\section{Conclusion}

Severe hypoglycemia is an important issue in the care of patients with diabetes, not in small part due to the fear that it imparts in patients and their caregivers. Hypoglycemia can occur in any patient with diabetes when glucose consumption exceeds supply, but certain descriptors are more characteristic of those patients at greatest risk for severe hypoglycemia - younger age, longer duration of diabetes, lower $\mathrm{HgbA}_{1 \mathrm{c}}$, higher insulin dose, lower BMI, male, Caucasian, underinsurance or low socioeconomic status, and the presence of psychiatric disorders[37]. Patients with a history of severe hypoglycemia are at increased risk of having recurrent episodes, but frequent episodes of mild hyperglycemia are not predictive of severe events. Patients must be especially careful at night, particularly after exercising during the day. 
Hypoglycemia does result in transient cognitive defects, which can affect concurrent activities, but has not been shown to significantly impact cognition, except at extremely low blood glucose values ( $<18 \mathrm{mg} / \mathrm{dl})$ [57]. Good glycemic control is essential in reducing the risk and delaying the onset of long-term complications of diabetes such as retinopathy, nephropathy, neuropathy, and neuropsychological effects, including decreased cognition, psychomotor efficiency, and motor speed[1]. The risk of long-term complications with poor blood glucose control outweighs the risks of hypoglycemia with good blood glucose control, and patients should be encouraged to aim for glucose concentrations in the physiologic range pre- and post-prandially. Advancements in care, including multiple daily injection therapy with ana$\log$ insulin, continuous subcutaneous insulin infusion, and continuous glucose monitoring, have each subsequently improved glycemic control and decreased risk of severe hypoglycemia.

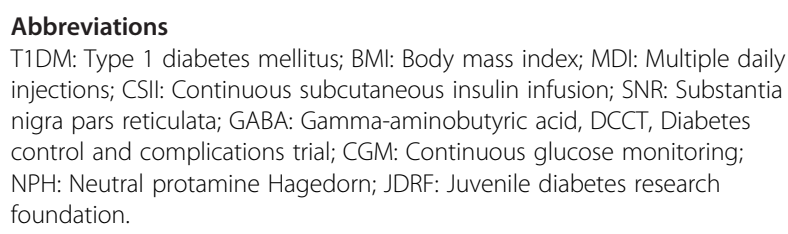

\section{Competing interests}

All authors do not have any Financial or Non- Financial Competing Interests to disclose.

\section{Authors' contributions}

$\mathrm{KL}$ made substantial contributions to conception, involved in drafting the manuscript and revising it critically for important intellectual content. VR actively involved in drafting the manuscript and revising it critically for important intellectual content. RH made substantial contributions to conception, involved in drafting the manuscript and revising it critically for important intellectual content and also given final approval of the version to be published. All authors read and approved the final manuscript.

\section{Author's information}

$\mathrm{RH}$ is the chief of the Division of Pediatric Endocrinology at Albert Einstein College of Medicine/ The Children's Hospital at Montefiore and is a very well-known Clinical Researcher in the field of type 1 diabetes mellitus.

\section{Author details}

'Baylor College of Medicine, One Baylor Plaza, Houston, Texas 77030, USA. ${ }^{2}$ Department of Pediatrics, Division of Pediatric Endocrinology, Albert Einstein College of Medicine, 1300 Morris Park Ave, Bronx, NY 10461, USA.

${ }^{3}$ Department of Pediatrics, Division of Pediatric Endocrinology, Albert Einstein College of Medicine/ The Children's Hospital at Montefiore, 3415 Bainbridge Ave, Bronx, NY 10467, USA.

Received: 25 January 2012 Accepted: 15 April 2012

Published: 20 June 2012

\section{References}

1. Hypoglycemia in the Diabetes Control and Complications Trial. The Diabetes Control and Complications Trial Research Group. Diabetes 1997, 46:271-286

2. Hypoglycemia and Seizures in Large Full-Term Neonates. AAP Grand Rounds 2006, 16:43-44.

3. Mitrakou A, Ryan C, Veneman T, Mokan M, Jenssen T, Kiss I, Durrant J, Cryer $P$, Gerich J: Hierarchy of glycemic thresholds for counterregulatory hormone secretion, symptoms, and cerebral dysfunction. Am J Physiol 1991, 260:E67-E74.

4. Defining and reporting hypoglycemia in diabetes: a report from the American Diabetes Association Workgroup on Hypoglycemia. Diabetes Care 2005, 28:1245-1249.

5. Swinnen SG, Mullins P, Miller M, Hoekstra JB, Holleman F: Changing the glucose cut-off values that define hypoglycaemia has a major effect on reported frequencies of hypoglycaemia. Diabetologia 2009, 52:38-41.

6. Gonder-Frederick LA, Snyder AL, Clarke WL: Accuracy of blood glucose estimation by children with IDDM and their parents. Diabetes Care 1991, 14:565-570

7. Jones TW, Davis EA: Hypoglycemia in children with type 1 diabetes: current issues and controversies. Pediatr Diabetes 2003, 4:143-150.

8. Clarke W, Jones T, Rewers A, Dunger D, Klingensmith GJ: Assessment and management of hypoglycemia in children and adolescents with diabetes. Pediatr Diabetes 2009, 10(Suppl 12):134-145.

9. Cryer PE, Davis SN, Shamoon H: Hypoglycemia in diabetes. Diabetes Care 2003, 26:1902-1912.

10. Graveling AJ, Warren RE, Frier BM: Blunted Counterregulatory hormone responses to hypoglycemia in young children and adolescents with well-controlled type 1 diabetes: response to the Diabetes Research in Children Network (DirecNet) Study Group. Diabetes Care 2010, 33:e67. author reply e68.

11. Dagogo-Jack SE, Craft S, Cryer PE: Hypoglycemia-associated autonomic failure in insulin-dependent diabetes mellitus. Recent antecedent hypoglycemia reduces autonomic responses to, symptoms of, and defense against subsequent hypoglycemia. J Clin Invest 1993, 91:819-828.

12. McAulay V, Deary IJ, Frier BM: Symptoms of hypoglycaemia in people with diabetes. Diabet Med 2001, 18:690-705.

13. Veliskova J, Chudomel O, Poon KL, Marshall B, Velisek L: The involvement of the substantia nigra pars reticulata in hypoglycemic seizures. Epilepsia 2007, 48(Suppl 5):106-108.

14. Velisek L, Veliskova J, Chudomel O, Poon KL, Robeson K, Marshall B, Sharma A, Moshe SL: Metabolic environment in substantia nigra reticulata is critical for the expression and control of hypoglycemia-induced seizures. J Neurosci 2008, 28:9349-9362.

15. Antony S, Peeyush Kumar T, Mathew J, Anju TR, Paulose CS: Hypoglycemia induced changes in cholinergic receptor expression in the cerebellum of diabetic rats. J Biomed Sci 2010, 17:7.

16. : Effect of intensive diabetes treatment on the development and progression of long-term complications in adolescents with insulindependent diabetes mellitus: Diabetes Control and Complications Trial. Diabetes Control and Complications Trial Research Group. J Pediatr 1994 125:177-188.

17. Frier BM: Morbidity of hypoglycemia in type 1 diabetes. Diabetes Res Clin Pract 2004, 65(Suppl 1):S47-S52.

18. Veneman TF: Diabetes mellitus and traffic incidents. Neth J Med 1996, 48:24-28.

19. Gonder-Frederick LA, Fisher CD, Ritterband LM, Cox DJ, Hou L, DasGupta AA, Clarke WL: Predictors of fear of hypoglycemia in adolescents with type 1 diabetes and their parents. Pediatr Diabetes 2006, 7:215-222.

20. Patton SR, Dolan LM, Henry R, Powers SW: Fear of hypoglycemia in parents of young children with type 1 diabetes mellitus. J Clin Psychol Med Settings 2008, 15:252-259.

21. Svoren BM, Volkening LK, Butler DA, Moreland EC, Anderson BJ, Laffel LM: Temporal trends in the treatment of pediatric type 1 diabetes and impact on acute outcomes. J Pediatr 2007, 150:279-285.

22. : Adverse events and their association with treatment regimens in the diabetes control and complications trial. Diabetes Care 1995, 18:1415-1427.

23. Chase HP, Lockspeiser T, Peery B, Shepherd M, MacKenzie T, Anderson J, Garg SK: The impact of the diabetes control and complications trial and humalog insulin on glycohemoglobin levels and severe hypoglycemia in type 1 diabetes. Diabetes Care 2001, 24:430-434.

24. Bulsara MK, Holman CD, Davis EA, Jones TW: The impact of a decade of changing treatment on rates of severe hypoglycemia in a populationbased cohort of children with type 1 diabetes. Diabetes Care 2004 27:2293-2298

25. DiMeglio LA, Pottorff TM, Boyd SR, France L, Fineberg N, Eugster EA: A randomized, controlled study of insulin pump therapy in diabetic preschoolers. J Pediatr 2004, 145:380-384. 
26. Litton J, Rice A, Friedman N, Oden J, Lee MM, Freemark M: Insulin pump therapy in toddlers and preschool children with type 1 diabetes mellitus. J Pediatr 2002, 141:490-495.

27. Hanas R, Adolfsson P: Insulin pumps in pediatric routine care improve long-term metabolic control without increasing the risk of hypoglycemia. Pediatr Diabetes 2006, 7:25-31.

28. Garg S, Moser E, Dain MP, Rodionova A: Clinical experience with insulin glargine in type 1 diabetes. Diabetes Technol Ther 2010, 12:835-846.

29. Fatourechi MM, Kudva YC, Murad MH, Elamin MB, Tabini CC, Montori VM: Clinical review: Hypoglycemia with intensive insulin therapy: a systematic review and meta-analyses of randomized trials of continuous subcutaneous insulin infusion versus multiple daily injections. J Clin Endocrinol Metab 2009, 94:729-740.

30. Pickup JC, Sutton AJ: Severe hypoglycaemia and glycaemic control in Type 1 diabetes: meta-analysis of multiple daily insulin injections compared with continuous subcutaneous insulin infusion. Diabet Med 2008, 25:765-774.

31. Bergenstal RM, Tamborlane W, Ahmann A, Buse JB, Dailey G, Davis SN, Joyce C, Peoples T, Perkins BA, Welsh JB, et al: Effectiveness of sensoraugmented insulin-pump therapy in type 1 diabetes. N Engl J Med 2010 363:311-320.

32. Raccah D, Sulmont V, Reznik Y, Guerci B, Renard E, Hanaire H, Jeandidier N, Nicolino M: Incremental value of continuous glucose monitoring when starting pump therapy in patients with poorly controlled type 1 diabetes: the RealTrend study. Diabetes Care 2009, 32:2245-2250.

33. Juvenile Diabetes Research Foundation Continuous Glucose Monitoring Study G, Beck RW, Hirsch IB, Laffel L, Tamborlane WW, Bode BW, Buckingham $B$, Chase P, Clemons R, Fiallo-Scharer R, et al: The effect of continuous glucose monitoring in well-controlled type 1 diabetes. Diabetes Care 2009, 32:1378-1383.

34. Juvenile Diabetes Research Foundation Continuous Glucose Monitoring Study G, Tamborlane WW, Beck RW, Bode BW, Buckingham B, Chase HP, Clemons R, Fiallo-Scharer R, Fox LA, Gilliam LK, et al: Continuous glucose monitoring and intensive treatment of type 1 diabetes. $N$ Engl J Med 2008, 359:1464-1476.

35. : Epidemiology of severe hypoglycemia in the diabetes control and complications trial. The DCCT Research Group. Am J Med 1991, 90:450-459.

36. Allen C, LeCaire T, Palta M, Daniels K, Meredith M, D'Alessio DJ: Risk factors for frequent and severe hypoglycemia in type 1 diabetes. Diabetes Care 2001, 24:1878-1881.

37. Rewers A, Chase HP, Mackenzie T, Walravens P, Roback M, Rewers M Hamman RF, Klingensmith G: Predictors of acute complications in children with type 1 diabetes. JAMA 2002, 287:2511-2518.

38. Donnelly LA, Morris AD, Frier BM, Ellis JD, Donnan PT, Durrant R, Band MM, Reekie G, Leese GP: Frequency and predictors of hypoglycaemia in Type 1 and insulin-treated Type 2 diabetes: a population-based study. Diabet Med 2005, 22:749-755.

39. Johns C, Faulkner MS, Quinn L: Characteristics of adolescents with type 1 diabetes who exhibit adverse outcomes. Diabetes Educ 2008, 34:874-885.

40. Auer RN: Hypoglycemic brain damage. Metab Brain Dis 2004, 19:169-175.

41. Puente EC, Silverstein J, Bree AJ, Musikantow DR, Wozniak DF, Maloney S, Daphna-lken D, Fisher SJ: Recurrent moderate hypoglycemia ameliorates brain damage and cognitive dysfunction induced by severe hypoglycemia. Diabetes 2010, 59:1055-1062

42. Diabetes C, Complications Trial/Epidemiology of Diabetes I, Complications Study Research G, Jacobson AM, Musen G, Ryan CM, Silvers N, Cleary P. Waberski B, Burwood A, et al: Long-term effect of diabetes and its treatment on cognitive function. N Engl J Med 2007, 356:1842-1852.

43. Musen $\mathrm{G}$, Jacobson AM, Ryan CM, Cleary PA, Waberski BH, Weinger $K$, Dahms W, Bayless M, Silvers N, Harth J, White N: Impact of diabetes and its treatment on cognitive function among adolescents who participated in the Diabetes Control and Complications Trial. Diabetes Care 2008, 31:1933-1938.

44. Austin EJ, Deary IJ: Effects of repeated hypoglycemia on cognitive function: a psychometrically validated reanalysis of the Diabetes Control and Complications Trial data. Diabetes Care 1999, 22:1273-1277.

45. Gaudieri PA, Chen R, Greer TF, Holmes CS: Cognitive function in children with type 1 diabetes: a meta-analysis. Diabetes Care 2008, 31:1892-1897.

46. McCarthy AM, Lindgren S, Mengeling MA, Tsalikian E, Engvall JC: Effects of diabetes on learning in children. Pediatrics 2002, 109:E9.
47. Strudwick SK, Carne C, Gardiner J, Foster JK, Davis EA, Jones TW: Cognitive functioning in children with early onset type 1 diabetes and severe hypoglycemia. J Pediatr 2005, 147:680-685.

48. Wysocki T, Harris MA, Mauras N, Fox L, Taylor A, Jackson SC, White NH: Absence of adverse effects of severe hypoglycemia on cognitive function in school-aged children with diabetes over 18 months. Diabetes Care 2003, 26:1100-1105.

49. Prolonged nocturnal hypoglycemia is common during 12 months of continuous glucose monitoring in children and adults with type 1 diabetes. Diabetes Care 2010, 33:1004-1008

50. Raju B, Arbelaez AM, Breckenridge SM, Cryer PE: Nocturnal hypoglycemia in type 1 diabetes: an assessment of preventive bedtime treatments. $J$ Clin Endocrinol Metab 2006, 91:2087-2092.

51. Tsalikian E, Mauras N, Beck RW, Tamborlane WV, Janz KF, Chase HP, Wysocki T, Weinzimer SA, Buckingham BA, Kollman C, et al: Impact of exercise on overnight glycemic control in children with type 1 diabetes mellitus. J Pediatr 2005, 147:528-534.

52. Woodward A, Weston P, Casson IF, Gill GV: Nocturnal hypoglycaemia in type 1 diabetes-frequency and predictive factors. QJM 2009, 102:603-607.

53. Taplin CE, Cobry E, Messer L, McFann K, Chase HP, Fiallo-Scharer R: Preventing post-exercise nocturnal hypoglycemia in children with type 1 diabetes. J Pediatr 2010, 157:784-788. e781.

54. Buckingham B, Wilson DM, Lecher T, Hanas R, Kaiserman K, Cameron F: Duration of nocturnal hypoglycemia before seizures. Diabetes Care 2008, 31:2110-2112.

55. Iseda I, Lins PE, Adamson U, Kollind M: Comment to: Hoi-Hansen T, Pedersen-Bjergaard U, Thorsteinsson B (2005) The Somogyi phenomenon revisited using continuous glucose monitoring in daily life. Diabetologia 48:2437-2438. Diabetologia 2006, 49:1706-1707. author reply 1708-1709.

56. Guillod L, Comte-Perret S, Monbaron D, Gaillard RC, Ruiz J: Nocturnal hypoglycaemias in type 1 diabetic patients: what can we learn with continuous glucose monitoring?. Diabetes Metab 2007, 33:360-365.

57. Brismar T, Hyllienmark L, Ekberg K, Johansson BL: Loss of temporal lobe beta power in young adults with type 1 diabetes mellitus. Neuroreport 2002, 13:2469-2473.

doi:10.1186/1687-9856-2012-19

Cite this article as: Lehecka et al:: Insight into hypoglycemia in pediatric type 1 diabetes mellitus. International Journal of Pediatric Endocrinology 2012 2012:19.

\section{Submit your next manuscript to BioMed Central and take full advantage of:}

- Convenient online submission

- Thorough peer review

- No space constraints or color figure charges

- Immediate publication on acceptance

- Inclusion in PubMed, CAS, Scopus and Google Scholar

- Research which is freely available for redistribution 